\title{
Interaction Effect of Nitrogen and Phosphorus on Growth, Flowering and Yield of Bird of Paradise (Strelitzia reginae)
}

\author{
Dishaben K. Patel", S.L. Chawla, Sudha Patil and Eerathi Sathyanarayana \\ Department of Floriculture and Landscape Architecture, ASPEE College of Horticulture and \\ Forestry, Navsari Agricultural University, Navsari - 396450, Gujarat, India \\ *Corresponding author
}

\section{A B S T R A C T}

\begin{tabular}{|l|}
\hline K e y w o r d s \\
Bird of paradise, \\
Nitrogen, \\
Phosphorus, \\
Flowering. \\
\hline Article Info \\
\hline $\begin{array}{l}\text { Accepted: } \\
\text { 19 July 2017 } \\
\text { Available Online: } \\
\text { 10 September } 2017\end{array}$ \\
\hline
\end{tabular}

An experiment was conducted at Floriculture Research Farm, ASPEE College of Horticulture \& Forestry, Navsari Agricultural University, Navsari to study the effect of nitrogen and phosphorus on growth, flowering and yield of bird of paradise in Large Plot Technique and data were analyzed in Completely Randomized Design with Factorial concept (FCRD) with nine treatment combinations and three replications. Combined application of nitrogen @ $30 \mathrm{~g}$ and phosphorus @ 15 g/plant/year $\left(\mathrm{N}_{2} \mathrm{P}_{2}\right)$ recorded significantly higher vegetative as well as flowering attributes. The same treatment also improved quality and yield of flowers of bird of paradise.

\section{Introduction}

Bird of paradise is one of the majestic flower crop grown in the regions having moderate subtropical and tropical climate. It is native to South Africa and an evergreen perennial, herbaceous, underexploited cut flower plant.

The brilliant colors and unusual appearance of the flower have made it exceptionally popular as cut flower. Therefore, the crop is cultivated in many parts of the world in order to produce cut flowers for both domestic and international markets. Hence, in some country, farmers have started growing this crop on commercial scale. Nutrition has direct influence on crop physiology because it plays a prime role in the production of any crop.
A suitable nutritional dose certainly helps in deciding the quantities and periods of fertilizer application for higher production and subsequent higher yields in bird of paradise cultivation. Nitrogen plays a vital role in metabolic activities of plants.

It is responsible for synthesis of protein, amino acids, nucleic acids, chlorophyll and protoplasm of cell which help in harvesting solar energy through chlorophyll compounds. Phosphorus serves as a structural component of cell constitutes like chloroplast and mitochondria, it is a part of sugar phosphates (ATP and ADP), which plays an inevitable role in photosynthesis and respiration, 
consequently leading to increase vegetative growth and flower production of plants. The present investigation was, therefore, undertaken in order to standardize the optimum dose of fertilization (nitrogen and phosphorus) in three years old bird of paradise plants.

\section{Materials and Methods}

The experiment on bird of paradise was laid out in Large Plot Technique and data were analyzed in Completely Randomized Design with Factorial concept (FCRD) during 2015 16 at Floriculture Research Farm, ASPEE College of Horticulture and Forestry, Navsari Agricultural University, Navsari, Gujarat.

Three levels of each of nitrogen viz., $\mathrm{N}_{1}: 20$, $\mathrm{N}_{2}: 30$ and $\mathrm{N}_{3}: 40 \mathrm{~g} \mathrm{~N} /$ plant/year and phosphorus viz., $\mathrm{P}_{1}: 10, \mathrm{P}_{2}: 15$ and $\mathrm{P}_{3}: 20 \mathrm{~g}$ $\mathrm{P} /$ plant/year were applied. Thus, there were nine treatment combinations with three replications. Nitrogen and phosphorus was applied in four and two equal doses, respectively.

Nitrogen and phosphorus were applied in the form of urea and Single Super Phosphate, respectively. The treatment was imposed on three year old bird of paradise plants to know the effects of nitrogen and phosphorus on growth, flowering and yield. The plants were planted at a spacing of $1.75 \mathrm{~m} \times 1.0 \mathrm{~m}$ under 50 per cent shade net. Observations on plant growth, flowering and yield attributing characters were recorded.

\section{Results and Discussion}

It is explicit from the data (Table 1) that among all the growth parameters under study, the interaction effect of nitrogen and phosphorus had significant effect on vegetative growth at $12^{\text {th }}$ month. The treatment combination of $\mathrm{N}_{2} \mathrm{P}_{2}(30 \mathrm{~g} \mathrm{~N}+15 \mathrm{~g}$
$\mathrm{P} /$ plant/year) recorded significantly higher plant height $(171.50 \mathrm{~cm})$, leaf length $(53.42$ $\mathrm{cm})$, leaf width $(19.67 \mathrm{~cm})$, leaves per clump (32.08) and suckers per plant (6.42).

The increase of vegetative growth characteristics due to combined application of nitrogen and phosphorus may be attributed to the fact that both $\mathrm{N}$ and $\mathrm{P}$ might have cumulative effect of nitrogen and phosphorus. Nitrogen plays a vital role in metabolic activities of plants. It is responsible for synthesis of protein, amino acids, nucleic acids, chlorophyll and protoplasm of cell which help in harvesting solar energy through chlorophyll compounds.

Phosphorus serves as a structural component of cell constitutes like chloroplast and mitochondria, it is a part of sugar phosphates (ATP and ADP), which plays an inevitable role in photosynthesis and respiration, consequently leading to increase vegetative growth and flower production of plants.

Similar results were found by Kumar and Mishra (2011) in the gladiolus, Chandana and Dorajeerao (2013) in gladiolus, Kumar and Kumar (2013) in China aster, Sharma et al., (2006) in African marigold, Barman et al., (2004) in Cymbidium, Ahirwar et al., (2012) in African marigold and Kaur and Kumar (1998) in pansy.

An interaction between nitrogen and phosphorus was also found significant with respect to various flowering parameters of bird of paradise (Table 2). The minimum days to flowering from initiation of inflorescence (40.75 days), maximum florets per bract (9.75), stalk length $(104.92 \mathrm{~cm})$, stalk diameter $(0.56 \mathrm{~cm})$, longevity of inflorescence (27.92 days), vase life (14.17 days) and inflorescence per plant per year (4.08) were found in the treatment combination of $\mathrm{N}_{2} \mathrm{P}_{2}$ $(30 \mathrm{~N}+15 \mathrm{P}$ g/plant/year). 
Table.1 Interaction effect of nitrogen and phosphorus on vegetative growth of bird of paradise

\begin{tabular}{|c|c|c|c|c|c|}
\hline Treatment & Plant height $(\mathrm{cm})$ & Leaf length $(\mathrm{cm})$ & Leaf width $(\mathrm{cm})$ & Leaves /clump & Suckers/plant \\
\hline $\mathrm{N}_{1} \mathrm{P}_{1}$ & 151.25 & 39.67 & 14.42 & 23.00 & 4.83 \\
\hline $\mathrm{N}_{1} \mathrm{P}_{2}$ & 153.08 & 43.42 & 15.75 & 25.17 & 4.92 \\
\hline $\mathrm{N}_{1} \mathrm{P}_{3}$ & 151.92 & 45.00 & 15.08 & 24.58 & 4.83 \\
\hline $\mathrm{N}_{2} \mathrm{P}_{1}$ & 157.00 & 43.42 & 18.08 & 26.17 & 5.25 \\
\hline $\mathrm{N}_{2} \mathrm{P}_{2}$ & 171.50 & 53.42 & 19.67 & 32.08 & 6.42 \\
\hline $\mathrm{N}_{2} \mathrm{P}_{3}$ & 159.33 & 47.67 & 16.92 & 26.75 & 5.25 \\
\hline $\mathrm{N}_{3} \mathrm{P}_{1}$ & 159.83 & 48.17 & 15.83 & 26.83 & 5.17 \\
\hline $\mathrm{N}_{3} \mathrm{P}_{2}$ & 165.17 & 48.75 & 18.50 & 27.75 & 5.75 \\
\hline $\mathrm{N}_{3} \mathrm{P}_{3}$ & 158.75 & 46.17 & 17.83 & 26.58 & \\
\hline C.D. at 5 \% & 3.25 & 2.91 & 1.35 & & 1.98 \\
\hline
\end{tabular}

Table.2 Interaction effect of nitrogen and phosphorus on flower quality and yield of bird of paradise

\begin{tabular}{|c|c|c|c|c|c|c|c|}
\hline Treatment & $\begin{array}{l}\text { Days to flowering } \\
\text { from initiation of } \\
\text { inflorescence }\end{array}$ & Florets/bract & $\begin{array}{l}\text { Stalk length } \\
\quad(\mathrm{cm})\end{array}$ & $\begin{array}{l}\text { Stalk diameter } \\
(\mathrm{cm})\end{array}$ & $\begin{array}{c}\text { Longevity of } \\
\text { inflorescence } \\
\text { (days) }\end{array}$ & $\begin{array}{l}\text { Vase life } \\
\text { (days) }\end{array}$ & $\begin{array}{c}\text { Inflorescence/plant/y } \\
\text { ear }\end{array}$ \\
\hline $\mathrm{N}_{1} \mathrm{P}_{1}$ & 45.25 & 7.75 & 98.42 & 0.49 & 23.83 & 10.83 & 2.58 \\
\hline $\mathrm{N}_{1} \mathrm{P}_{2}$ & 41.33 & 8.00 & 100.83 & 0.53 & 24.42 & 12.42 & 3.17 \\
\hline $\mathrm{N}_{1} \mathrm{P}_{3}$ & 43.75 & 8.17 & 100.42 & 0.51 & 25.58 & 12.33 & 3.08 \\
\hline $\mathrm{N}_{2} \mathrm{P}_{1}$ & 42.50 & 7.92 & 99.50 & 0.52 & 25.08 & 12.75 & 3.17 \\
\hline $\mathrm{N}_{2} \mathrm{P}_{2}$ & 40.75 & 9.75 & 104.92 & 0.56 & 27.92 & 14.17 & 4.08 \\
\hline $\mathrm{N}_{2} \mathrm{P}_{3}$ & 41.42 & 8.42 & 101.92 & 0.54 & 25.92 & 12.58 & 3.25 \\
\hline $\mathrm{N}_{3} \mathrm{P}_{1}$ & 44.92 & 8.33 & 102.33 & 0.53 & 26.17 & 13.17 & 3.08 \\
\hline $\mathrm{N}_{3} \mathrm{P}_{2}$ & 43.08 & 8.67 & 101.00 & 0.54 & 26.42 & 13.17 & 3.50 \\
\hline $\mathrm{N}_{3} \mathrm{P}_{3}$ & 41.08 & 8.25 & 100.92 & 0.50 & 25.33 & 12.58 & 3.00 \\
\hline C.D. at $5 \%$ & 1.68 & 0.78 & 3.01 & 0.03 & 1.67 & 0.98 & 0.32 \\
\hline
\end{tabular}


The increase in the flower quality characters are might be due to nitrogen and phosphorus which are essential constituents which helps in the formation of starch and sugar in plant body, it is also very important in forming carbohydrate and translocation of starch resulting in improved plant growth which might have favoured increase in flowering as well as qualitative characters. This finding was also supported by Acharya and Dashora (2004) in marigold, Rahayanavar (1985) in chrysanthemum, Sigedar et al., (1991) in calendula, Sarkar et al., (1991) in calendula, Singatkar et al., (1995) in gaillardia, Sharma et al., (2006) in African marigold and Chawla et al., (2007) in chrysanthemum.

The increase in number of inflorescences per plant per year may be attributed to the fact that both $\mathrm{N}$ and $\mathrm{P}$ are essential plant nutrients and both these nutrients ( $\mathrm{N}$ and $\mathrm{P}$ ) might have cumulative effect in enhancing number of flowers in the present study. Dorajeerao et al., (2012) also reported the similar results in chrysanthemum with the application of 150 $\mathrm{kg}$ of nitrogen along with $100 \mathrm{~kg}$ phosphorus.

Higher concentration of both $\mathrm{N}$ and $\mathrm{P}$ nutrients are enough to reduce growth of plant and yield of flowers. This might be because of the excessive nutrients concentration being able to cause an imbalance in other essential nutrients which also reduce growth and yield of plant.

\section{References}

Acharya, M. M., and Dashora, L. K. 2004. Response of graded levels of nitrogen and phosphorus on vegetative growth and flowering in African marigold (Tagetes erecta Lin.). J. Ornam. Hort., 7 (2): 179-183.

Ahirwar, M. K., Ahirwar, K. and Megha Shukla 2012. Effect of plant densities, nitrogen and phosphorus levels on growth, yield and quality of African marigold. Ann.Pl. Soil Res., 14(2): 153155.

Barman, D., Rajni, K., Naik, S. K. and Upadhyaya, R. C. 2004. Effect of nitrogen, phosphorus and potassium on growth and flowering of Cymbidium. $J$. Ornam. Hort., 7(3-4): 235-238.

Chandana, K., and Dorajeerao, A. V. D. 2013. Effect of graded levels of nitrogen and phosphorus on growth and yield of gladiolus (Gladiolus grandiflorus L.) cv. White Prosperity in costal A.P., India. Plant Archives, 14(1): 143-150.

Chawla, S. L., Mohammed, S., Mahawer, L. N. and Jain, M. C. 2007. Effect of nitrogen and phosphorus on vegetative growth and flower yield of chrysanthemum. Ann. Agric. Res., 28(1): 25-28.

Dorajeerao, A. V. D., Mokashi, A. N., Patil, V. S., Venugopal, C. K., Lingaraju, S. and Koti, R. V. 2012. Effect of graded levels of nitrogen and phosphorus on growth and yield of garland chrysanthemum (Chrysanthemum coronarium L.). Karnataka J. Agric. Sci., 25(2): 224-228.

Kaur, R., and Kumar, R. 1998. Effect of nitrogen, phosphorus and plant spacing on seed yield in pansy (Viola tricolor L.) cv. Swiss Giant. J. Ornam. Hort., 1(1): 21-25.

Kumar, A., and Kumar, R. 2013. Effect of nitrogen and phosphorus levels on growth, flowering and yield of China aster (Callistephus chinensis L.). Plant Archives, 14(1): 475-477.

Kumar, R., and Misra, R. L. 2011. Studies on nitrogen in combination with phosphorus or potassium on gladiolus cv. Jester Gold. Indian J. Hort., 68(4): 535-539.

Rahayanavar, C.S., 1985. Studies on the influence of intra spacing with different levels of nitrogen and phosphorus on 
growth and flower production in chrysanthemum (Chrysanthemum morilium Ramat.) cv. Mattur. Thesis Abst, 11(4): 279-280.

Sarkar, D., Bandopadhya, A. and Pal, P. 1991. Effect of different levels of nitrogen and phosphorus on growth and yield of (Calendula officinalis L.) var. Lemon Queen. Hort. J., 4(1):57-60.

Sharma, D. P., Patel, M. and Gupta, N. 2006. Influence of nitrogen, phosphorus and pinching on vegetative growth and floral attributes in African marigold
(Tagetes erecta Linn.). J. Ornam. Hort., 9(1): 25-28.

Sigerdar, P.D., Anserwadekar, K.W. and Rodge, B.M. 1991. Effect of different levels of nitrogen, phosphorus and potassium on growth and yield of Calendula officinalis L., South Indian Hort., 39(5): 308-311.

Singatkar, S.S., Sawant, R.B., Ranpise, S.A. and Wavhal K.N. 1995. Effect of different levels of $\mathrm{N}, \mathrm{P}$ and $\mathrm{K}$ on growth and flower production of gaillardia. $J$. Maharashtra Agric. Unv., 20(3): 392394.

\section{How to cite this article:}

Dishaben K. Patel, S.L. Chawla, Sudha Patil and Eerathi Sathyanarayana. 2017. Interaction Effect of Nitrogen and Phosphorus on Growth, Flowering and Yield of Bird of Paradise (Strelitzia reginae). Int.J.Curr.Microbiol.App.Sci. 6(9): 1566-1570. doi: https://doi.org/10.20546/ijcmas.2017.609.192 